\title{
Support from Leaders and Co-Workers: Which is More Significant in Implementing Islamic Nursing Behaviour?
}

\author{
Puguh Widiyanto $^{1 *}$, Zuhri Almisbah ${ }^{1}$, Siti Sangadatul Wahidah Alqudsiyah ${ }^{1}$ \\ ${ }^{1}$ Department of Nursing Science, Universitas Muhammadiyah Magelang, Magelang, Indonesia \\ *Corresponding author.Email: puguh.widiyanto@ummgl.ac.id
}

\begin{abstract}
Patient assessment of nurses' soft skills in hospitals is a crucial indicator of the quality of nursing services. Professional nursing care by implementing Islamic values is an excellent nursing service expected by patients, especially in countries with a Muslim majority population. Therefore, this study was conducted to identify the support of leaders and co-workers in the practice of Islamic nursing. This research was conducted by crosssectional method during August-September 2019 at Aisyiyah Muntilan Hospital, Magelang, Indonesia. Data were collected from respondents by electronic questionnaire, and then bivariate analysis was performed using the Spearman Rank test ( $\alpha=0.05$ CI 95\%). The results showed a significant relationship between the support of leaders and co-workers with Islamic nursing behaviour, with $\mathrm{p}=0.001 ; \mathrm{r}=0.47$ for leader support and $\mathrm{p}=$ $0.001 ; \mathrm{r}=0.62$ for co-workers' support. In conclusion, the better the support of leaders and co-workers will improve Islamic nursing behaviour.
\end{abstract}

Keywords: nurses, leaders, co-workers, Islamic nursing behaviour

\section{INTRODUCTION}

Behaviour is the result or response of various experiences gained by individuals as well as a very broad interaction with others and their environment that can be observed and has a specific frequency, duration, and good purpose. Behavioural responses to stimuli have various forms that are classified into 2, namely closed behaviour and overt behaviour [1]. Islamic behaviour is the attitude of a person to others and their environment that contains moral values in accordance with the will of Khaliq (God) [2].

Muslim population in Indonesia reaches $91.94 \%$, a strong reason to create an Islamic-based business including health services and hospitals. Currently, Islamic-based hospitals that provide Islamic services have not been sufficient fair with the community needed [3]. Aisyiah Muntilan Hospital as a hospital with Islamic nuance is expected to be able to create Islamic activities by applying Islamic values in all services area, including nursing care. Nurses are a crucial resource in-hospital services because they communicate directly with patients.

Lawrence W. Green [1] explain that behaviour is a response that arises from the nurse due to external stimuli. There are three factors for the performed of Islamic behaviour, namely predisposing factors (knowledge, attitudes, and beliefs), reinforcing factors (physical environment, infrastructure, and worship facilities provided by health services), and driving factors (support from leaders and coworkers) [1]. For example, health services in Surakarta Islamic Hospital apply four characters to their Islamic services, including Rabbaniyah, Akhlaqiyah, al Waqi'iyah and Insaniyah. In addition, four basic concepts for Islamic services also apply including al Yusru, al Tadarruj, al Ihsan and Mardhatillah. Surakarta Islamic Hospital also implements of Islamic values (Islamization) to the entire service areas, such as patient services, medical expense services, maintenance of patient administration data, maintenance of the hospital's physical environment, and other non-medical services [4]. We see, there is a consistent management role in order to realize these Islamic practices. Therefore, we conducted a study at Aisyiyah Muntilan Hospital, which has the same ideological characteristics as the Surakarta Islamic Hospital. In this study, we focus on assessing the role of leaders and co-workers in applying nursing care that applies Islamic values.

\section{METHOD}

This research was conducted by cross-sectional method with a survey during August-September 2019 at Aisyiyah Muntilan Hospital, Magelang. Data was collected from respondents who filled out an electronic ranking scale questionnaire sent via mobile phones. Then, bivariate analysis was performed using the Spearman Rating test ( $\alpha$ $=0.05 \mathrm{CI} 95 \%$ ). Criteria, population characteristics, and research objectives are also determined. Inclusion criteria refer to: (1) nurses who are willing to become respondents, (2) nurses in inpatient rooms, and (3) nurses who have worked for more than three months. We also exclude respondents when they are not included as criteria or they are on work leave. Taking into account the strengths and weaknesses of the study, we expect a good correlation coefficient (0.430) between variables [5]. 


\section{RESULTS AND DISCUSSION}

\subsection{The Data}

Correlations between leader and co-worker support independently and overall towards Islamic nursing behaviour are presented in Table 1, Table 2, and Table 3, respectively. A statistically significant correlation was found between leader support and co-workers support with Islamic caring behaviour $(\mathrm{p}<0.05)$. The type of correlation is positive and the level of correlation is fair (0.47 and 0.62$)$.

Table 1 Relationship between leader's support and Islamic caring behaviour

\begin{tabular}{|c|c|c|c|c|c|c|c|c|c|}
\hline \multirow{3}{*}{ Islamic Caring Behaviour } & \multicolumn{6}{|c|}{ Co-Worker's Support } & \multirow{3}{*}{ Total } & \multirow{3}{*}{$p$} & \multirow{3}{*}{$\mathbf{r}$} \\
\hline & \multicolumn{2}{|c|}{ Good } & \multicolumn{2}{|c|}{ Fair } & \multicolumn{2}{|c|}{ Lack } & & & \\
\hline & $\mathbf{n}$ & $\%$ & $\mathbf{n}$ & $\%$ & $\mathbf{n}$ & $\%$ & & & \\
\hline Good & 1 & 2.0 & 6 & 12.2 & 0 & & 7 & & \\
\hline Fair & 37 & 75.5 & 5 & 10.2 & 0 & & 42 & 0.001 & 0.62 \\
\hline Lack & 0 & & 0 & & 0 & & & & \\
\hline Total & 38 & & 11 & & 0 & & 49 & & \\
\hline
\end{tabular}

Table 2 Relationship between co-worker's support and Islamic caring behaviour

\begin{tabular}{|c|c|c|c|c|c|c|c|c|c|}
\hline \multirow{3}{*}{ Islamic Caring Behaviour } & \multicolumn{6}{|c|}{ Co-Worker's Support } & \multirow{3}{*}{ Total } & \multirow{3}{*}{$p$} & \multirow{3}{*}{$\mathbf{r}$} \\
\hline & \multicolumn{2}{|c|}{ Good } & \multicolumn{2}{|c|}{ Fair } & \multicolumn{2}{|c|}{ Lacking } & & & \\
\hline & $\mathbf{N}$ & $\%$ & $\mathbf{N}$ & $\%$ & $\mathbf{N}$ & $\%$ & & & \\
\hline Good & 1 & 2.0 & 6 & 12.2 & 0 & & 7 & & \\
\hline Fair & 37 & 75.5 & 5 & 10.2 & 0 & & 42 & 0.001 & 0.62 \\
\hline Lack & 0 & & 0 & & 0 & & & & \\
\hline Total & 38 & & 11 & & 0 & & 49 & & \\
\hline
\end{tabular}

Table 3 Relationship between leaders and co-worker's support with Islamic caring behaviour

\begin{tabular}{|lccc|}
\hline \multicolumn{1}{|c}{ Variable } & $\begin{array}{c}\text { OR } \\
\text { (exp.B) }\end{array}$ & $\begin{array}{c}\text { 95\% CI } \\
\text { (exp.B) }\end{array}$ & $\boldsymbol{p}$ \\
\hline Leaders & 0.000 & $0.00-0.001$ & 0.998 \\
Co-Worker's Support & 0.028 & $0.02-0.371$ & 0.007 \\
\hline
\end{tabular}

\subsection{Discussion}

\subsubsection{Relationship between leader's support and Islamic caring behaviour}

The results showed there was a positive relationship between leader support and Islamic caring behaviour with the Spearman rho test, obtained a $\mathrm{p}$ value $=0.001$ ( $\mathrm{p}$ value $<0.05$ ). Leadership style has a significant influence simultaneously on employee performance so that overall leadership style contributes very significantly in improving employee performance [6]. Support from leaders is done through encouragement to employees, so they can show measurable work performance and have a positive impact. Nurse work performance is essential, especially in hospitals that guarantee high-quality services to make clients feel satisfied with the services provided. Leader support is also manifested through good communication and behaviour, thus making employees comfortable and enthusiastic in carrying out the work given [7].

Hasibuan in As'ad, Sidin, \& Kapalawi explained that a leader is someone who utilizes the authority of his leadership, directing subordinates to do some of his work in achieving organizational goals [8]. While leadership is a way for someone to influence employee behaviour, so they want to work together and work productively to achieve organizational goals. The leader provides instructions, feedback, and suggestions related to applying Islamic caring behaviour [9-10]. The leader also figures that provide feedback on nurses' work performance in implementing Islamic caring behaviour, including providing praise and opportunities for promotion [11].

\subsubsection{Relationship between co-worker's support and Islamic caring behaviour}

The statistical tests using the Spearman test obtain $\mathrm{p}$ value $=0.001>0.05(\alpha=0.05)$ which means there is a relationship between co-worker's support and Islamic caring behaviour. Co-workers have a significant relationship with the performance of nurses, because co-workers are willing to give advice, encourage, and assist in carrying out their duties [1]. Dhyani states that the goal the basis of forming deep relations human life is to obtain a support system. An individual has a support system consisting of several different sources to get strength and courage to fight in the midst of a difficult situation in his life [12].

Co-workers play an important role in establishing comfortability in the workplace, as well as providing opportunities for nurses to see work performance among others. It is important to improve the nursing experience, 
Retrieved from

verbal persuasion, and positive affective state related to their work [13]. Support from fellow nurses can accelerate nursing community to implement Islamic caring behaviour in the hospital. Finally, the existence of social support from the nursing community can help nurses to confidence to implement Islamic caring behaviour.

\section{CONCLUSION}

Based on data obtained and processed during the study, we found that:

a. A statistically significant correlation was found between leader's and Islamic caring behaviour $(p=0.001<\alpha=$ 0.05 ). The type of correlation is positive and the level of correlation is fair $(0.47)$.

b. A statistically significant correlation was found between co-worker's support and Islamic caring behaviour $(\mathrm{p}=$ $0.001<\alpha=0.05$ ). The type of correlation is positive and the level of correlation is fair (0.62).

c. The most significant correlation between leader's support and co-worker's support with Islamic caring behaviour is co-worker's support ( $\mathrm{p}=0.007<\alpha=0.05$ ).

\section{ACKNOWLEDGMENTS}

Thank you to the Director of the Hospital Aisyiyah Muntilan, Magelang, who provided the opportunity for researchers to collect data. The researchers also thanked the respondents.

\section{REFERENCES}

[1] Notoatmodjo, S. Promosi Kesehatan dan Perilaku Kesehatan (Edisi Revi). Jakarta: PT Rineka Cipta., 2014

[2] Miswanto, A. Seri Studi Islam : Agama, Keyakinan, dan Etika. (Z. Arofi, Ed.). Magelang: Pusat Pembinaan dan Pengembangan Studi Islam Universitas Muhammadiyah Magelang (P3SI UMM)., 2012

[3] Ayuningtyas, D., \& Fazriah, H. Analisis Potensi Pasar dan Atribut Pelayanan Rumah Sakit Islam Depok. Kesmas: National Public Health Journal, 3(1), 16. https://doi.org/10.21109/kesmas.v3i1.238., 2008

[4] Sunawi. Konsep Pelayanan Kesehatan Islami di Rumah Sakit (Tinjauan Aplikasi di Rumah Sakit Islam Surakarta). Digital Times, (Unknown), No Pages.
http://eprints.ums.ac.id/20804/18/Naskah Publikasi.pdf ., 2012

[5] Akoglu, H, User's Guide to Correlation Coefficients, Turkish Journal of Emergency Medicine, 18(3), 91-93. 2018

[6] Putra, C. B., \& Al, E. Pengaruh Gaya Kepemimpinan Direktif, Suportif, dan Partisipatif terhadap Kinerja Karyawan. Retrieved from http://administrasibisnis.studentjournal.ub.ac.id/index.p hp/jab/article/viewFile/93/1659., 2013

[7] Pramana, R. A. Hubungan Tuntutan Kerja dan Dukungan Atasan dengan Burnout pada Perawat Pelaksana di Ruang Rawat Inap RSUD Muntilan Kabupaten Magelang Tahun 2019. Universitas Muhammadiyah Magelang., 2019

[8] As'ad, A., Sidin, H. A. I., \& Kapalawi, I. (2013). Hubungan Kepuasan Kerja dengan Kinerja Perawat di Unit Rawat Inap Rumah Sakit Universitas Hasanudin Tahun 2013, 1-14. Retrieved from https://core.ac.uk.,2013

[9] Chi, H., Yeh, H., \& Wu, S. F. (2014). How WellBeing Mediates the Relationship Between Social Support and Teaching Effectiveness. Journal of Education and Learning, 3(4), 117-130.,2014

[10] Savas, A. C., \& Dos, I. Teacher Views on Supervisors' Roles in School Development. Ozean Journal of Social Sciences, 6(1), 24-35., 2013

[11] Bataineh, O. Sources of Social Support Among Special Education Teachers in Jordan and Their Relationship to Burnout. International Education, 39(1), 65-78., 2009

[12] Dhyani, R. A Study of Multidimensional Social Support System Among School Teachers. The International Journal of Indian Psychology, 2(1), 125131., 2014

[13] Santoso, E., \& Setiawan, J. L. Peran Dukungan Sosial Keluarga, Atasan, dan Rekan Kerja terhadap Resilient Self-Efficacy Guru Sekolah Luar Biasa. Jurnal Psikologi, 45(1), 27-39.

https://doi.org/10.22146/jpsi.25011., 2018 